\title{
Interplanting Secondary Crops into Existing Strawberry Fields. ${ }^{1}$
}

\section{J.R. Duval, E.A.Golden, and A. Whidden ${ }^{2}$}

To increase the utility of land preparation, existing plastic mulch, and micro-irrigation, strawberry growers in the Plant City area often plant secondary crops among winter annual strawberries. Seeds or transplants are planted 5-6 weeks before the end of the strawberry production season, dependent on strawberry variety. This practice allows for establishment of the secondary crop while the harvesting of strawberries continues. An early start on secondary crops allows producers to take advantage of a marketing window when few other regions are producing. The most common secondary crops are squash, cantaloupe, pickles, and peppers. Strawberry is a high value, insurable crop. However, insurance policies do not allow for intercropping of strawberry with secondary crops. This practice, under current guidelines, invalidates policies.

A study was instituted that examined the effect of interplanting squash, cantaloupe, and pickles from seed, and cantaloupe and pepper from transplants, on yield of strawberry. In 2003, secondary crops were planted on 28 Feb, 7 March, 14 March, and 21 March, into a stand of 'Strawberry Festival' strawberries. In 2004, the plantings occured on 1 March, 8 March and 15 March into a stand of 'Camarosa' strawberries.
Seeds or transplants were planted among strawberries spaced 15 inches apart in row and 12 inches between rows. No strawberry plants were removed before planting the secondary crop. Cantaloupe spacing was 30 inches down the middle of the bed, squash and pickle spacing was 15 inches in the middle of the bed, and pepper spacing was a double row on the bed 15 inches between plants and 10 inches between rows. Fertilization was increased from $0.75 \mathrm{lbs} \mathrm{N}$ A/d (IFAS recommendation, Maynard and Olson, 2002) to $0.83 \mathrm{lbs} \mathrm{N} \mathrm{A/d,} \mathrm{a} 10 \%$ increase to compensate for additional plants in the field. Data was collected from the time of planting the second crop into the plots until the end of the harvest period. Data was collected for strawberry marketable yield, number of marketable berries, and cull fruit until 31 March, 2003 and 29 March 2004. Data was subjected to ANOVA procedures using SAS statistical software.

No significant differences were detected among treatments for marketable weight (Figures $1 \& 2$ ), number of berries (Figures $3 \& 4$ ), or number of cull fruit (data not presented). Additionally, the harvest of the strawberry crop was unhindered by the secondary crop.This data suggest that strawberry yields are

1. This document is HS988, one of a series of the Horticultural Sciences Department, Florida Cooperative Extension Service, Institute of Food and Agricultural Sciences, University of Florida. Original publication date July 29, 2004. Visit the EDIS Web Site at http://edis.ifas.ufl.edu.

2. JR Duval, assistant professor, EA Golden, biological scientist, Gulf Coast Research and Education Center, Dover: A Whidden, horticultural extension agent, Hillsborough County, Florida Cooperative Extension Service, IFAS, University of Florida, Gainesville, FL 32611

The Institute of Food and Agricultural Sciences (IFAS) is an Equal Employment Opportunity - Affirmative Action Employer authorized to provide research, educational information and other services only to individuals and institutions that function without regard to race, creed, color, religion, age, disability, sex, sexual orientation, marital status, national origin, political opinions or affiliations. For information on obtaining other extension publications, contact your county Cooperative Extension Service office. Florida Cooperative Extension Service / Institute of Food and Agricultural Sciences / University of Florida / Larry R. Arrington, Interim Dean 
unaffected by interplanting with squash, pickles, cantaloupe, or peppers planted up to 31 days before the end of strawberry harvest. Two procedures must be followed to keep insurance valid: 1- keep strawberry density constant (do not remove any plants when planting the second crop); 2- apply only pesticides that are labeled for both crops.

Research shows that intercropping with winter annual strawberries does not negatively affect late season strawberry harvest. Therefore, this practice should not be a reason to invalidate strawberry producers' crop insurance as long as strawberry planting density remains the same and proper pesticide selection is followed.

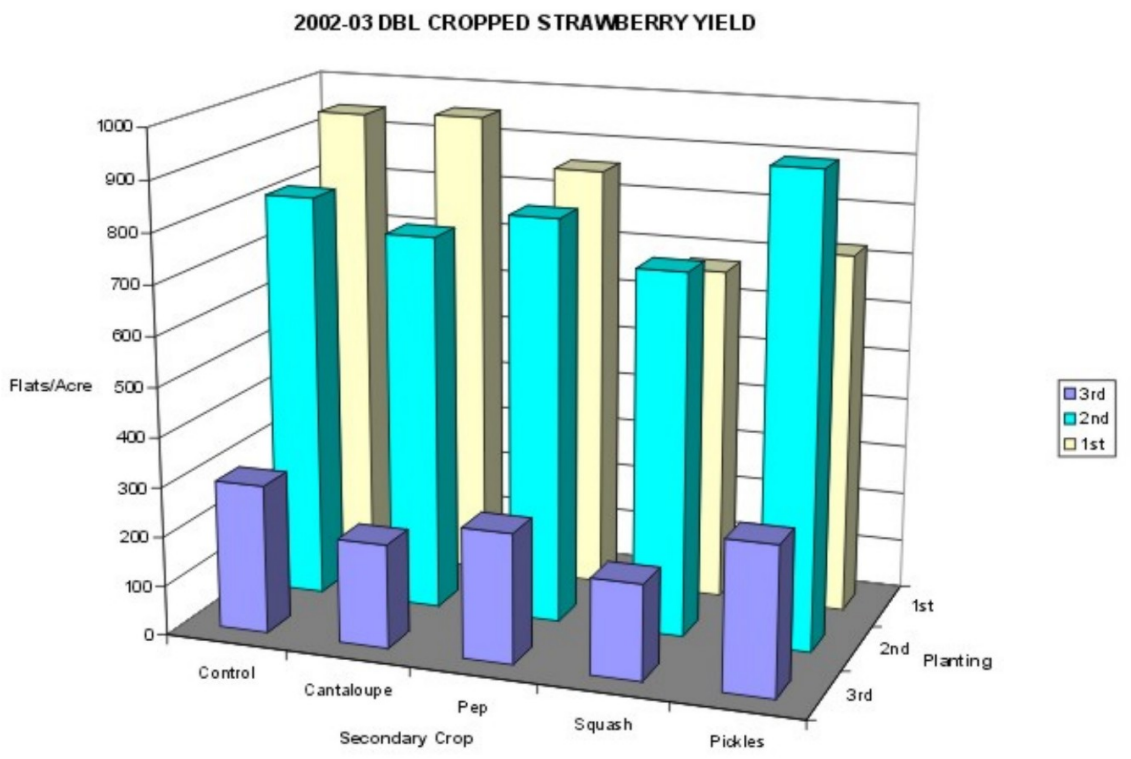

Figure 1. 2002-2003 Marketable Flats/Acre 


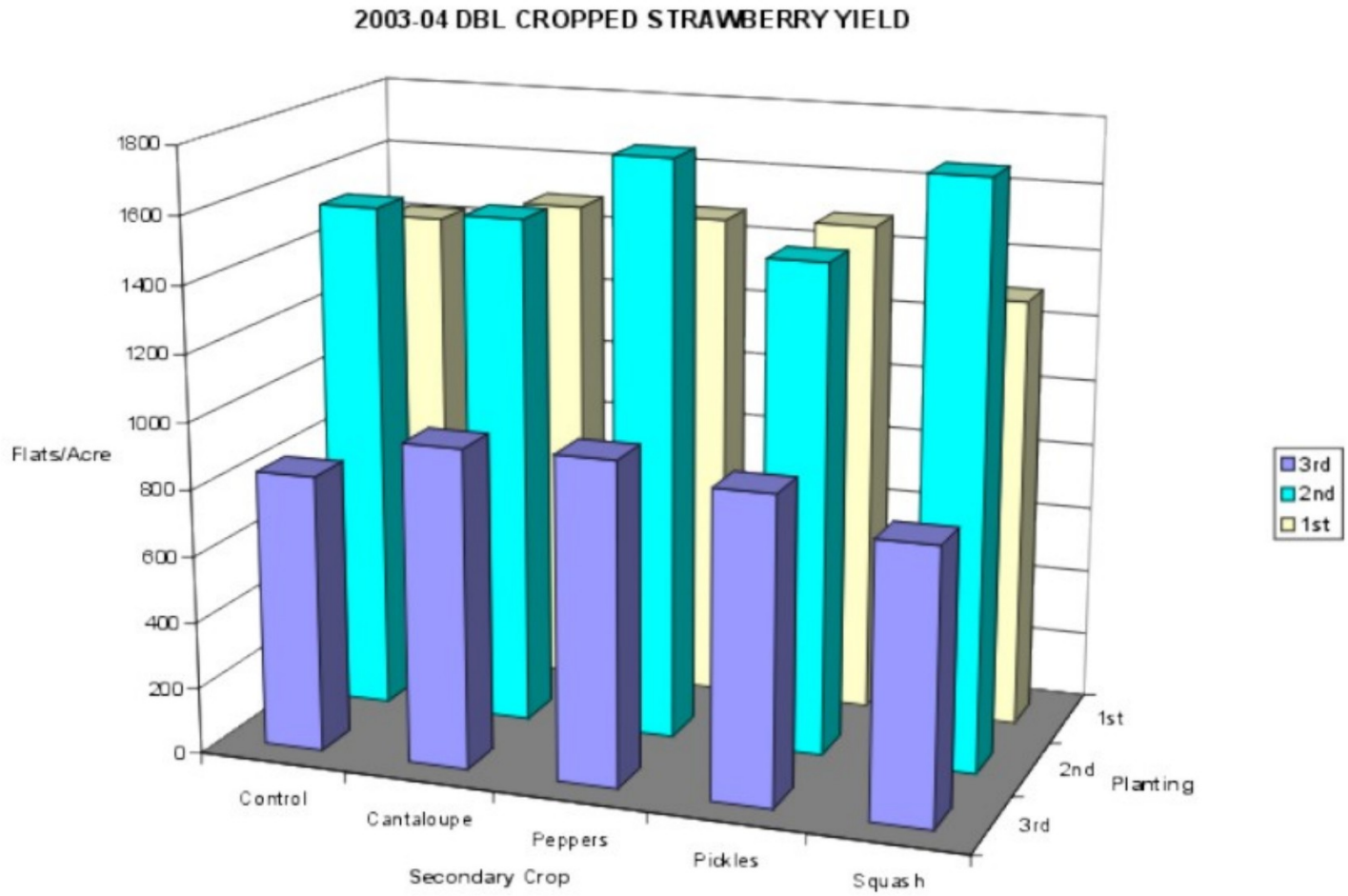

Figure 2. 2003-04 Marketable Flats/Acre 


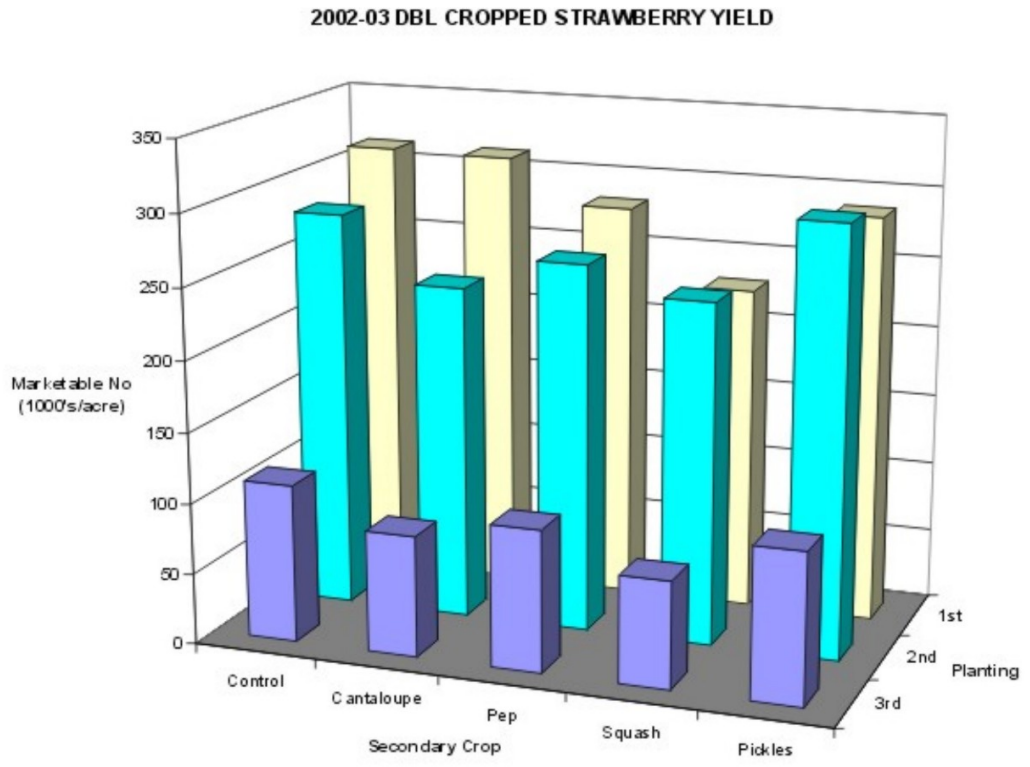

Figure 3. 2002-03 Marketable Number of Fruit/Acre

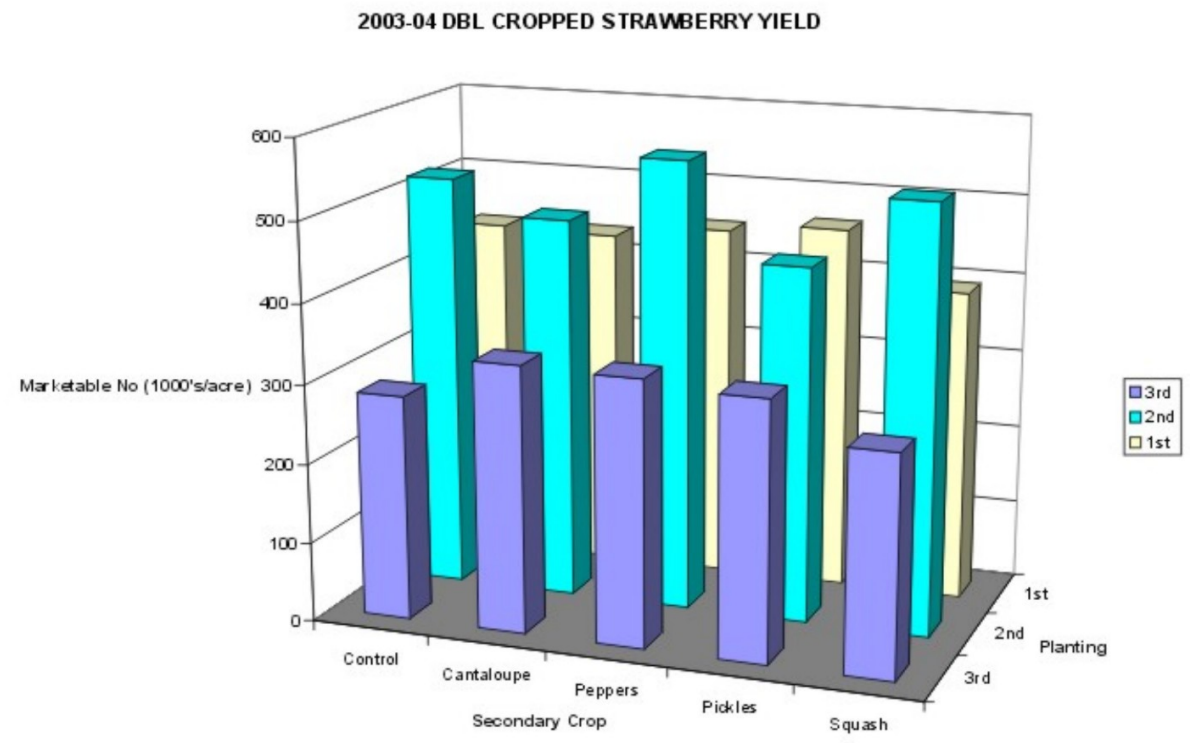

Figure 4. 2003-04 Marketable Number of Fruit/Acre 